\title{
FEATURES OF THE USE OF RESOURCE POTENTIAL IN PEASANT FARMS
}

\author{
Serhii Kalchenko ${ }^{1}$, Denis Yeremenko' ${ }^{2}$, Diana Hrybova ${ }^{3}$
}

\begin{abstract}
The purpose of the article is to analyse the modern features of the development of peasant farms as a component of domestic agricultural production, taking into account their double socio-economic nature. Methodology. When writing the article, such methods were used as abstract-logical method - for revealing the theoretical foundations of the functioning of peasant farms, monographic - in the study of the views of scientists on the problems of peasant farms' development, as well as the study of foreign experience of state policy in this area, analysis and synthesis - for assessing the performance of peasant farms of consumer and product types. Results. The current state of development of the national agrarian sector is characterized by the special significance of small forms of agricultural production, which in the domestic legal field, scientific and statistical literature are defined as individual peasant farms, households, rural households, peasant farms, and others. Ensuring the development of small forms of agrarian production is an important part of the effective functioning of the domestic agricultural sector as a component of the national economic system. In turn, this leads to the need to analyse the features of the use of available resource potential, as well as the economic performances of representatives of this group of farmers. Practical implications. According to the results of the study, the differentiated nature of the functioning of this component of agrarian production is substantiated. A comparative analysis of typical representatives of households of commercial, subsistence and commercial, and subsistence farming is conducted. It is proved that farms of the commodity group show the highest results from the sale of the final product, at the same time, households of the consumer-commodity group more efficiently use land resources. In determining the strategic development directions for this component of agrarian production, a preliminary differentiation of the household is required in accordance with the level of marketability and the nature of the use of available resource potential.
\end{abstract}

Key words: agricultural production, peasant farms, efficiency, differentiation.

JEL Classification: Q10, Q12, Q16

\section{Introduction}

The current state of development of the national agrarian sector is characterized by the special significance of small forms of agricultural production, which in the domestic legal field, scientific and statistical literature are defined as individual peasant farms, households, rural households, peasant farms, and others. Despite its rather amorphous official status, this group of farmers occupies an important place among producers of agricultural products. In particular, their share in the overall structure during 2016 in grain and leguminous crops was more than $20 \%$, sunflower - $15 \%$, vegetables $85 \%$, fruit and berry crops - more than $80 \%$, in meat and milk production sectors - respectively 36 and $74 \%$.

Ensuring the development of small forms of agrarian production is an important part of the effective functioning of the domestic agricultural sector as a component of the national economic system. In turn, this leads to the need to analyse the features of the use of available resource potential, as well as the economic performances of representatives of this group of farmers. It should be noted that at the moment there is no single system of methodological approaches to assess the effectiveness of their functioning, which also negatively reflects on the level of reliability of information about the general condition and prospects for the further development of representatives of small forms of agricultural production.

The above circumstances, in our opinion, require optimization of theoretical and methodological support in the field of study of specifics of using the resource potential of this segment of domestic

\footnotetext{
Corresponding author:

${ }^{1}$ Tavria State Agrotechnological University, Ukraine.

E-mail: przixl136@gmail.com

${ }^{2}$ Tavria State Agrotechnological University, Ukraine.

E-mail: eremenko.denis.mobile@gmail.com

${ }^{3}$ Bohdan Khmelnytskyi Melitopol State Pedagogical University, Ukraine.

E-mail: gribovadiana@ukr.net
} 
agricultural production, taking into account not only purely economic but also the social aspects of its representatives. The latter is particularly relevant given the fact that the modern peasant farms of Ukraine also carry out village-forming functions.

\section{World experience in ensuring the effective use of resource potential of peasant farms}

It should be noted that under present conditions, in the vast majority of developed countries, the functioning of peasant farms is carried out on a commodity basis, which involves the implementation of appropriate state support measures, among which should be noted the promotion of the development of service cooperatives.

Analysing the peculiarities of foreign experience in the development of farm enterprises, one should note the important role of state institutions that ensure the effective operation of the small agricultural business through the implementation of a system of regulatory and organizational measures to increase their level of competitiveness. It should be noted that, in general, the nature of the cooperation of state institutions with representatives of agrarian entrepreneurship involves not direct targeted assistance to a specific agrarian, but assistance in the formation of appropriate mechanisms to enable farmers to independently solve the problems of optimizing the use of resource potential.

Farm enterprises in developed countries are not able to fully compete with large agricultural companies; therefore, the very fact of the existence of a favourable state policy in this area is not objectionable to anyone. Particularly relevant is the European practice of cooperative construction precisely for countries with the post-planned economy, where ensuring the effective operation of cooperative organizations as full-fledged components of market mechanism that is based on competition, requires appropriate measures by state institutions.

A positive example in this aspect can be the policy of stimulating the cooperative movement in the agricultural sector carried out by the Ministry of Agriculture of the Republic of Kazakhstan. Taking into account the insufficient activity of Kazakh farmers in the field of cooperative construction, the government has developed a system of regulatory and organizational measures aimed at changing the relevant negative practices. In particular, the government draft law "On Cooperation", submitted to the Parliament of the Republic of Kazakhstan, establishes the priority of cooperative organizations towards individual farmers in terms of receiving state aid.

As we see, the problem of avoiding the monopoly dictate of intermediaries is international for small agricultural producers. The solution to this problem turns out to be universal too, namely, the creation of a system of cooperative organizations that provide their members with the appropriate services. The practical experience of the countries that have joined the EU and successfully develop agrarian production is very valuable. One such example is the state policy of the Polish government.

To improve the professional level of persons employed in agriculture in Poland, state support for educational activities of state and private institutions and organizations is provided. The subject of study includes: studying the minimum requirements for the compliance of the person prior to conducting the agricultural activity, economy and management in agricultural production, the popularization of new directions of agricultural activity in order to seek higher income; the organization of animal welfare and environmental protection.

As we see, the issue of increasing the efficiency of using the resource potential of peasant farms in the developed countries of the world involves not only the provision of targeted assistance, stimulation of the development of cooperative construction, but also the implementation of advisory and educational measures aimed at raising the qualification level of members of household.

\section{Theoretical aspects of the functioning of peasant farms in Ukraine}

It should be noted that one of the features of operation of the peasant farms of Ukraine is their heterogeneity, both in terms of industry and socio-economic nature. Despite the fact that the main purpose of economic activity of representatives of this segment of agrarian production is to ensure the development of a specific peasant family in accordance with the principles of extended reproduction, each of them solves this problem, taking into account the state of resource potential (first of all, land and labour resources), as well as the stage of functioning of the family itself (creation, flowering or decay), which, in turn, determines the range of goals set and measures for their solution.

We propose the following differentiation of peasant farms, based on the level of merchantability of their products as the main indicator of the nature of economic activity.

Commercial farming. These are unregistered farms or individual enterprises where hired labour is actively used. The activities of agrarians in most cases coincide with the spheres, in which farmers and private traders are employed and the vast majority of their products are in need of further processing or used as a material component of other productions.

Commercial and subsistence farming. Households organize economic activity in such a way that a smaller part of the production is created to meet the food needs of the family, and the vast majority of production is for sale.

Subsistence farming. Unite the least socially active part of the population, who for various reasons suspend 
their technological development. The products manufactured, mainly crop plants, are mostly used for self-sufficiency. A small part of the output is for sale, and the sales process has a primitive character.

In order to study the features of the functioning of each of the groups of peasant farms, we conducted questionnaires in 516 households operating on the territory of the Steppe zone of Ukraine. According to the results of the questionnaire, one typical household from each group is selected.

Subsistence farming. It consists of one person of retirement age, who is able to work but has no ability to perform long-term physically tedious operations. The main sources of income are government payments and proceeds from the sale of agricultural products, mainly fruits and berries. Hired labour is not used.

Commercial and subsistence farming. It consists of four people; two of them are of retirement age. All household members are able-bodied; however, only two can carry out physically exhausting types of work. The revenue part of the budget is formed at the expense of state payments (wages and pensions), as well as proceeds from the sale of agricultural products, in particular, fruits and vegetables. Hired labour is not used.

Commercial farming. It consists of two persons of working age, one of whom is a pensioner, but both are able to perform physically exhausting types of work. The main source of income is the sale of agricultural products, as well as cash receipts in the form of pension payments and wages. Since the main direction of agrarian production is the cultivation of cereals, the household involves hired labour with its own agricultural machinery for seasonal field work (ploughing, harvesting, etc.).

\section{Analysis of activities of peasant farms in Ukraine}

In order to analyse the results of the abovementioned peasant farms, we have applied a methodology developed by the specialists of the NSC "Institute of Agrarian Economics" of the National Academy of Agrarian Sciences of Ukraine, which involves taking into account of the labour costs of members of a household in the monetary equivalent (Sabluk, MeselVeseliak, Luzan, 2001). Based on this methodology, the following indicators were calculated: "conditional salary", "conditional net income", and "conditional level of profitability".

A comparative analysis of economic performances of the peasant farms indicates that commercial farming shows the best indicators, where the means of mechanization are actively used, and the cultivated production is intended not for consumption but for further sale. Thus, in particular, the value of the conditional net income is 40 thousand UAH, which is 6 and 10 times higher than the similar indicators of households of commercial-subsistence farming and subsistence farming (Table 1). The conditional level of profitability is $104.9 \%$, exceeding the corresponding value of commercial-subsistence farming and subsistence farming by 40 and 80 points.

At the same time, it should be noted that this result is achieved at the expense of the consumer nature of the use of land resources and the application of simplified technological schemes. This conclusion is confirmed by the results of an analysis of the level of efficiency of land and labour resources in peasant farms. Households of commercial and subsistence type show the highest value of conditional net income per 1 hectare, which is more than 3 times the same indicator of commercial farming and 1.5 times - of subsistence farming (Table 2). In the subsistence economy, there are also high relative indicators of sales revenue, as well as gross income, but the active use of manual labour negatively affects the level of conditional net income and conditional profitability.

Thus, we see that the economic activity of different groups of peasant farms is based on its own principles of functioning, which determines the peculiarities of the use of the resource potential. In this regard, it should be noted that the key to the effective development of

Table 1

The efficiency of economic activity in peasant farms

\begin{tabular}{|c|l|c|c|c|}
\hline № & \multicolumn{1}{|c|}{ Indicators } & Subsistence farming & $\begin{array}{c}\text { Commercial-subsistence } \\
\text { farming }\end{array}$ & Commercial farming \\
\hline 1 & Number of members, persons & 1 & 4 & 2 \\
\hline 2 & Land area, ha & 0,04 & 0,42 & 10 \\
\hline 3 & Cost of manufactured production, UAH & 4838,0 & 27161,7 & 78300,0 \\
\hline 4 & Revenues from sales, UAH & 1917,0 & 16617,0 & 78300,0 \\
\hline 5 & Labour costs, man-hour & 194,0 & 1126,4 & 2285,5 \\
\hline 6 & Costs of production, UAH & 240,0 & 2760,9 & 23128,6 \\
\hline 7 & Conditional salary, UAH & 1280,4 & 7433,9 & 15084,3 \\
\hline 8 & Gross income, UAH (4-6) & 1677,0 & 13856,1 & 55171,4 \\
\hline 9 & Conditional net income, UAH (8-7) & 396,6 & 6422,2 & 40087,1 \\
\hline 10 & Conditional level of profitability, $\%$ & 26,1 & 63,0 & 104,9 \\
\hline
\end{tabular}

Source: according to the results of the questionnaire 
Table 2

The efficiency of the use of land and labour resources in peasant farms*

\begin{tabular}{|l|c|c|c|}
\hline \multicolumn{1}{|c|}{ Indicators } & Subsistence farming & Commercial-subsistence farming & Commercial farming \\
\hline Per 1 ha & & & 7830,0 \\
\hline - revenues from sales, UAH & 47925,0 & 39564,3 & 2312,9 \\
\hline - costs of production, UAH & 6000,0 & 6573,6 & 5517,1 \\
\hline - gross income, UAH & 41925,0 & 32990,7 & 1508,4 \\
\hline - conditional salary costs, UAH & 32010,0 & 17699,8 & 4008,7 \\
\hline - conditional net income, UAH & 9915,0 & 15291,0 & 39150,0 \\
\hline Per 1 member of household & & & 11564,3 \\
\hline - revenues from sales, UAH & 1917,0 & 4144,3 & 27585,7 \\
\hline - costs of production, UAH & 240,0 & 690,2 & 7542,2 \\
\hline - gross income, UAH & 1677,0 & 3464,0 & 20043,6 \\
\hline - conditional salary costs, UAH & 1280,4 & 1858,5 & 1605,6 \\
\hline - conditional net income, UAH & 396,0 & & \\
\hline
\end{tabular}

Source: according to the results of the questionnaire

peasant farms, the transformation of their commercial share into family farms, is to ensure the diversification of sectoral trends in this segment of agricultural production, using the positive aspects of economic activity inherent in all groups of the domestic peasantry.

\section{Conclusions}

In such a way, ensuring the effective use of the resource potential of peasant farms is an important component of the competitive development of the agrarian sector of the national economy. In developed countries, appropriate measures include material and logistical, organizational, and information support. One of the problems of its introduction is the heterogeneous nature of domestic peasant farms, a high share of households of subsistence and subsistence-commercial types, which activities are carried out in accordance with some other principles. According to the research results, the need to analyse peculiarities of economic activities of peasant farms in Ukraine has been proved.

Based on the data of the anonymous questionnaire, the differentiated character of the functioning of this component of agrarian production is substantiated. Using an alternative methodology for evaluating the results of the production and commercial activities of peasant farms, a comparative analysis of typical representatives of households of the commercial, subsistence-commercial, subsistence farming is conducted. It is proved that farms of the commercial group show the highest results from the sale of the final product, at the same time, the households of the subsistence-commercial economy more efficiently use land resources.

The importance of creating conditions for accelerating the transition of farms of the subsistence and commercial group to the commercial principles of economic activity is substantiated. The article stresses the need to ensure the systematic development of peasant farms in Ukraine as a full-fledged component of domestic agricultural production.

The direction of further research should be the development of a strategy for the competitive development of peasant farms in the system of agrarian production, taking into account the specified commodity differentiation and specifics of the use of available resource potential. Its main purpose should be to create conditions for increasing the number of peasant farms of the commercial type by increasing the level of efficiency of the use of available resource potential.

\section{References:}

Goryov, V. P., Zbarsky, V. K. (2011). Male pidpryiemnytstvo: postupy rozvytku, problem [Small entrepreneurship: progression, problems]. (in Ukrainian)

Diesperov, V. S. (2015). Tendentsii rozvytku silskykh domohospodarstv [Trends in rural household development]. Ekonomika APK, 5, 70-72. (in Ukrainian).

Sabluk, P. T., Mesel-Veseliak, V. Ia., Luzan, Yu. Ia. (2001). Efektyvnist silskohospodarskoho vyrobnytstva v osobystykh hospodarstvakh hromadian [Efficiency of agricultural production in private households of citizens]. (in Ukrainian)

Zhuk, V. M. (2017). Neformalni instytuty selianstva u modeliuvanni reform ta ahrarnoi polityky: teoriia i praktyka [Informal institutions of the peasantry in the modeling of reforms and agrarian policy: theory and practice]. Ekonomika APK, 9, 5. (in Ukrainian)

Kondratiev, N. D. (1991). Ryinok hlebov i ego regulirovanie vo vremya voynyi i revolyutsii [The bread market and its regulation during the war and revolution]. (in Russian)

Lupenko, Yu. O. (2017). Stan ta perspektyvy rozvytku silskykh terytorii [Status and prospects of development of rural territories]. Ekonomika APK, 6, 5. (in Ukrainian) 
Chayanov, A. V. (1989). Krestyanskoe hozyaystvo: Izbrannyie trudyi [Peasant Farm: Selected Works]. (in Russian) Chelyntsev, A. N. (1928). Russkoe selskoe khoziaistvo pered revoliutsyei [Russian agriculture before the revolution]. (in Russian)

Malik, M. Ya., Zaiats, V. M. (2013). Teoretychni zasady ta napriamy transformatsii osobystykh selianskykh hospodarstv [Theoretical principles and directions of transformation of personal peasant farms]. Ekonomika APK, 5, 87-95. (in Ukrainian)

Malik, M. Ya., Shpykuliak, O. G. (2018). Tendentsii i perspektyvy rozvytku osobystykh selianskykh hospodarstv [Development trends and prospects of individual peasant farms]. Ekonomika APK, 1, 11. (in Ukrainian) 